\title{
The next great migration: the story of movement on a changing planet
}

\author{
Sonia Shah: Bloomsbury, London, 2020, 388 pp, \$18.59, ISBN 978-1526626646
}

Gad Perry (D)

Received: 30 June 2020 / Accepted: 12 July 2020/Published online: 17 July 2020

(C) Springer Nature Switzerland AG 2020

In early 2020, when Covid-19 started dominating the world's attention, a colleague recommended a book on pandemics by Shah (2016). It was eerily prescient, given current events and the repeated claim that nobody could have predicted them. Moreover, it also was a good read. When another book from Ms. Shah, a prize-winning investigative journalist, was announced, I rushed to pre-order it. Unfortunately, it turned out to be disappointing.

The next great migration begins with the author in southern California, looking for Euphydyas editha butterflies. At the start of the first chapter, Shah tells the story of the decline and climate-related range shifts of this butterfly, which Parmesan (1996) made famous in the climate-change literature. (As an aside, it is not always clear to me what sources this book relies on. There is a references section and numbered, chapterby-chapter notes, but these do not correspond to explicit referrals in the text.) By page 7, however, Shah turns to her main topic, human migrations and bias against migrants. This, of course, is also a timely topic in the United States and elsewhere, and Shah devotes most of the book to citing scientists and others who claimed human migration would lead to various disasters, then exposing the errors and intentional

\section{G. Perry ( $\square)$}

Department of Natural Resource Management, Texas

Tech University, Lubbock, TX 79409, USA

e-mail: Gad.Perry@ttu.edu manipulations that often underlie such admonitions and the suffering that follows. Occasionally, though, she returns to biological and conservation issues (both butterfly and Dr. Parmesan appear again later in the book, for example).

Bias, racism, and intolerance of human migration is the main topic of the book, but biologists both dead and living are often dragged into the fray. The father of taxonomy gives his name to Chap. 3, "Linnaeus's loathsome harlotry." Much of the chapter is given to deriding globe-travelling Europeans of the 1700s for claiming to have met and for displaying in their museums "women touted as mermaids, Hottentots, and troglodytes" (p. 68-69). Unlike Buffon, presented as his "rival," Linnaeus would not accept dispersal as a major explanation for modern distributions. Rather than stick to the question of whether dispersal is important or not, as she effectively does later, Shah takes an ad-hominem approach and paints Linnaeus as a sex-obsessed failure and sometimes-fraud who refused "to admit that Europeans shared kinship with the foreigners they considered primitive and savage and possibly biologically alien" (p. 72). Linnaeus is accused of dividing humanity into different species, though his text actually names them as subspecies. This is an important distinction.

Human population growth is the topic of Chap. 6, in which Paul Ehrlich, Nazi horrors, $r$-vs.-K selection, environmental and general racism, coercive 
population control in India, and eugenics all mix suggestively but disjointedly. For example, we learn (p. 172-174) that John Thanton raised bees, practiced ophthalmology, was a member of the Audubon Society and the Nature Conservancy, and co-founded a Planned Parenthood branch - and was also a believer in zero population growth who "considered foreigners biologically alien" (p. 174). No support of this claim is given, nor is it clear to me what relation his bees, medical practice, or civic society involvement have to do with the implied claim.

Biological invasions are the topic of Chap. 8, named "the wild alien" (pp. 219-251), which begins with birders enjoying the fall migration in New Jersey. By the second page, those birders "condemn [Phragmites] reeds on principle, based on their foreign origins and conspicuous health" (p. 220). Invasives are then abandoned for a bit, in favor of more scattershot coverage. Darwin and his interest in dispersal lead to plate tectonics and long-distance dispersal, and Shah makes much of the trouble many biologists once had in accepting it - presumably because this rejection supposedly establishes a trend of scientific bias against migration as a whole. Although she mentions the Movement Ecology conference in Jerusalem in 2006, the organizer and still one of the leaders in the field (who also named it), Ran Nathan, is not credited or cited. Returning to invasion biology, Shah invokes (p. 245) a common generalization: only $10 \%$ of introduced species become established and only $10 \%$ of those become problematic. Therefore, "condemning all newcomers as inevitably damaging blames them for transgressions committed by 1 percent or less of their members." This is a frequent misunderstanding that has plagued the "antiinvasion-biology" literature, confounds "invasive species" with non-natives, and erects a disturbing strawman: invasion biology "condemn[s] all newcomers as inevitably damaging." Although the term "invasive species" has, at times, been used rather too loosely, the distinction has been clarified often enough that a serious search would have easily unearthed some of the many references to this. Incidentally, the "tens rule" is problematic, not least because "the proposed $10 \%$ value was not based on a model or other defensible concept or argument" and "is not supported by currently available evidence" (Jeschke and Pyšek 2018).
Thompson (2014) and his camels, as well as unnamed others, are recycled at length (p. 246-247) to make five points: (1) introduced species "failed to fulfill invasion biology's predictions" ("Zebra mussels cannot be blamed for the collapse of native clams, which face a number of [other] challenges"); (2) nonnatives have some positive impacts (zebra mussels help by "filtering water and providing food for fish and waterfowl"); (3) non-natives do not always displace native species (Thompson is given as the source for statements that purple loosestrife is mostly reviled for "being conspicuously successful" and moreover, "in places where they've been for a while, they tend to decline"-Simberloff [2015] has already pointed out this is simplistic and inaccurate); (4) classifying “species as either 'native' or 'alien' is one of the organizing principles of conservation" (a quote she takes from Warren [2007]) is simplistic because of migrations; and 5) non-natives can cause ecosystem shifts "on remote islands," but even there, "it isn't only newcomers that disrupt and encroach on locals. Natives do, too." These look a lot like the five points made by Thompson (2014) and addressed by Simberloff (2015).

The scene now shifts to Mauna Loa, Hawaii, where vegetation restoration efforts face two realizations. First, "efforts to rid a patch of forest of intrusive newcomers failed miserably ... invasion of species on the move appeared unstoppable" (p. 247). This is also a recurrent theme of Thompson (2014). Second, the effort "wasn't just futile. It also seemed unnecessary. ... Whole functional groups were missing" from the native ecosystem, which is why "the newcomers who followed thrived the way they did" (p. 248). Asked what is wrong with the non-natives, one of the leaders of the effort admits "I don't know" (p. 249). These are both issues worth discussing, I think. What should we do in the many cases where eradication cannot be achieved? And is it possible to generalize that in many cases new arrivals settle into unoccupied niches? If so, does it follow, as Shah implies, that they do little damage and may perhaps even support native species and thus be beneficial? We may, as Shah and others have repeatedly suggested, not have given such questions sufficient attention-but she does not offer any real insight either.

In one way, this book is as prescient as Shah's (2016) previous one: her consideration of race, racism, and the way that "others" are treated in so many places 
across the globe. The pandemic has created openings for migrants in many countries to be scapegoated for supposedly spreading Covid-19, for example. The scientific community has not always been innocent of racism by commission, as Shah is not the first to point out, nor by omission (Anonymous 2020). Like others, we are also susceptible to unconscious bias based on gender, religion (or lack thereof), race, sexual orientation, and so on. Conservation has its own, rarelyacknowledged faults in this arena (Potvin et al. 2001; Cannon 2020). Managers intent on addressing biological invasions have not always been open to discussion with local communities, often to their detriment and that of their project (Perry and Perry 2008; Perry et al. 2020a). At times, non-natives and cultural identity are intermixed in complex ways (e.g., Albeck-Ripka 2020). We have sometimes been accused of xenophobia and racism (see Simberloff 2003). Shah does not go quite that far in discussing invasive species, though the implication is there.

Like Ms. Shah's, mine is an immigrant family. My mother was born on a different continent than I was, speaking a language that had a different alphabet; my children are native to a third continent and have a different mother tongue yet again. I understand her frustration with the racist and anti-immigrant rhetoric so common at the moment, whether it is cries of "Jews will not replace us" in Charlottesville, Virginia, USA in 2017 or ongoing reports that the current ruling party of India has actively tolerated, enabled, and maybe even promoted anti-Muslim violence. I share her disgust, as expressed in her Acknowledgments (p. 321), at the perversion of science that underlies some of this phenomenon and the communal silence that has enabled it. Nonetheless, passion for a topic does not always translate into clarity, coherence, or conciseness, and in this book all three suffer in ways that a good editor may have mitigated. Shah raises points which should be interesting to readers of this journal, but rather than offer a meaningful discussion, she sometimes ignores relevant but inconvenient research or connects unrelated dots. S.J. Gould's (1996) "the mismeasure of man" is one notable omission.

Unlike her previous book (Shah 2016), I cannot recommend this one. But I believe we need to examine ourselves as well, and not just in the context of discrimination. As a journal editor, I often told unhappy authors that if reviewers misinterpreted their manuscript, there is probably some improvement possible that would enhance clarity and reduce misunderstanding in future versions. I do not know all the authors of "anti-invasion-science" reviewed in this journal (e.g., Simberloff 2003, 2015, 2016), but Ms. Shah is clearly an intelligent, capable, often insightful reporter. What are we doing wrong, then, that makes her and others so often badly misjudge our intent or ignore our message? There are certainly better non-technical books on invasion biology (e.g., Baskin 2013), so why do some continue to see what we do as a form of racism? How is "willful ignorance" allowed to guarantee that biological invasions will continue despite ample warning (Perry et al. 2020b)? More broadly, why has the scientific community had relatively little success convincing the rest of the world about evolution, climate change, and the need for conservation in general? Why are policy responses to the current medical crisis, and individual ones in the growing anti-vaccination community, so different from those being recommended by medical experts? In addition to various explanations blaming others, however justified, we need to ask what we are doing wrong. Are we training scientists to effectively communicate with the public and rewarding them sufficiently for doing so? Or at least creating the infrastructure to accurately and effectively translate science for a non-technical audience? And if not, what are we going to do about it?

\section{References}

Albeck-Ripka L (2020) Majestic icon or invasive pest? A war over Australia's wild horses. New York Times, June 28, 2020. https://www.nytimes.com/2020/06/28/world/ australia/brumbies-horses-culling.html. Downloaded 28 June 2020

Anonymous (2020) Black Lives Matter in ecology and evolution. Nat Ecol Evol. https://doi.org/10.1038/s41559-0201250-2

Baskin Y (2013) A plague of rats and rubbervines: the growing threat of species invasions. Island Press, Washington, DC

Cannon S (2020) Decolonizing conservation: a reading list. Blog posted 9 June 2020. https://saracannon.ca/2020/06/ 09/decolonizing-conservation-a-reading-list/. Accessed 25 June 2020

Gould SJ (1996) The mismeasure of man. WW Norton, New York 
Jeschke J, Pyšek P (2018) Tens rule. In: Jeschke JM, Heger T (eds) Invasion biology: hypotheses and evidence. CAB International, Wallingford, 124-132

Parmesan C (1996) Climate and species' range. Nature 382:765-766

Perry D, Perry G (2008) Improving interactions between animal rights groups and conservation biologists. Conserv Biol 22:27-35

Perry G, Sarge MA, Perry D (2020a) Alternative facts and alternative views: scientists, managers, and animal rights activists. In: Angelici FM, Rossi L (eds) Problematic wildlife II: new conservation and management challenges in the human-wildlife interactions. Springer, Cham, pp 421-450

Perry G, Curzer H, Farmer M, Gore ML, Simberloff D (2020b) Historical, ethical, and (extra)legal perspectives on culpability in "accidental" species introductions. Bioscience 70:60-70

Potvin C, Kraenzel M, Seutin G (eds) (2001) Protecting biological diversity: roles and responsibilities. McGillQueen's Press-MQUP, Montreal
Shah S (2016) Pandemic: tracking contagions, from cholera to ebola and beyond. Sarah Crichton Books, New York

Simberloff D (2003) Confronting introduced species: a form of xenophobia? Biol Invasions 5:179-192

Simberloff D (2015) Where do camels belong? The story and science of invasive species. Biol Invasions 17:1927-1929

Simberloff D (2016) Jacques Tassin: La grande invasion: Qui a peur des especes invasives? Biol Invasions 18:295-297

Thompson K (2014) Where do camels belong? The story and science of invasive species. Profile Books, London

Warren CR (2007) Perspectives on the 'alien' versus 'native' species debate: a critique of concepts, language and practice. Prog Hum Geogr 31:427-446

Publisher's Note Springer Nature remains neutral with regard to jurisdictional claims in published maps and institutional affiliations. 